\title{
Redesain Sistem Pengangkatan dan Pemberhentian Hakim di Indonesia
}

\author{
Idul Rishan \\ Fakultas Hukum Universitas Islam Indonesia \\ Jln. Tamansiswa No. 158 Yogyakarta \\ IdulRizhan@gmail.com
}

\begin{abstract}
Abstrak
This study reviews the redesign of the appointment and dismissal of judges in Indonesia. This is a prescriptivenormative judicial research conducted using the legislation approach, historical approach, and conceptual approach. The study concluded that the redesign of the judge appointment and dismissal system can be formulated with a variety of formulations. First, it is by organizing a constitutional basis to realign the will of judicial independence and by acknowledging the existence of an independent state organ in the constitution to rearrange the complicated power relations of the Supreme Court, the Judicial Commission and the Constitutional Court. Second, it is by carrying out the merit in the judge appointment system to maintain the constellation of the checks and balances principle. After reforming the mechanism of judge appointment, then the third one is by initiating the course of judge impeachment in an integrative manner as a form of accountability of the judiciary power in the non-judicial realm.
\end{abstract}

Keywords: Redesign, appointment and dismissal, judge

\begin{abstract}
Abstrak
Penelitian ini mengkaji tentang redesain pengangkatan dan pemberhentian hakim di Indonesia. Jenis penelitian ini yuridis normatif yang bersifat preskriptif. Pendekatan yang digunakan adalah pendekatan peraturan perundang-undangan, pendekatan historis, dan pendekatan konseptual. Hasil penelitian menunjukkan bahwa redesain sistem pengangkatan dan pemberhentian hakim dapat dirumuskan dengan beberapa formulasi. Pertama, menata landasan konstitusional dengan meluruskan kembali kehendak independensi peradilan, mengakui eksistensi organ negara independen di dalam konstitusi, hingga mengatur kembali benang kusut relasi kekuasaan Mahkamah Agung, Komisi Yudisial, dan Mahkamah Konstitusi. Kedua, mengusung merit sistem pengangkatan hakim dengan menjaga konstelasi prinsip checks and balances. Setelah melakukan pembenahan dalam mekanisme pengangkatan hakim, maka yang ketiga adalah menggagas jalur impeachment hakim secara integratif sebagai wujud akuntabilitas kekuasaan yudikatif dalam ranah non yustisi.
\end{abstract}

Kata Kunci; Redesain, pengangkatan dan pemberhentian, hakim 


\section{Pendahuluan}

Salah satu aspek fundamental dalam blueprint kekuasaan yudikatif di masa reformasi adalah pengaturan pengangkatan dan pemberhentian hakim di Indonesia. Mengapa demikian, tentu terdapat korelasi antara sistem pengangkatan hakim (judicial recruitment process/judicial appointment) dengan jaminan independensi peradilan, begitu juga sistem pemberhentian hakim (judicial disimissal process) dengan akuntabilitas peradilan. Masing-masing sistem tersebut membawa pengaruh besar terhadap penyelenggaraan kekuasaan yudikatif.

Sistem pengangkatan hakim (judicial recruitment process), merupakan instrumen yang dibutuhkan untuk melahirkan sosok hakim yang berintegritas dan kapabilitas. Tidak heran tesis Oddete Buittendam menjadi dasar teori yang tidak terbantahkan. Good judge are not born but made. Artinya hakim yang baik itu hanya lahir melalui sistem yang baik. Ibarat menjadi pembenaran catatan historis telah membuktikan di era orde lama dan orde baru sistem rekruitmen hakim sangat beraroma politis. ${ }^{1}$ Tidak heran jabatan kehormatan hakim sebagai penjaga keadilan diobral dan harus tunduk terhadap keinginan atau hasrat korup para penguasa.

Sementara itu pada tataran sistem pemberhentian hakim (judicial disimissal process), merupakan instrumen pertanggungjawaban politik seorang hakim terhadap warga negara. Artinya sebagai ruh dari nilai-nilai demokrasi, seorang hakim dituntut akuntabel dalam ranah yustisi maupun non yustisi kepada setiap warga negara.

Metode tambal sulam konstitusi yang dirajut pada masa transisi tampaknya mencoba mengakomodir masing-masing instrumen tersebut. Buah manis amandemen konstitusi mendorong lahirnya peran organ negara independen dalam sistem pengangkatan hakim dan pemberhentian hakim. Suatu penerobosan yang cukup memberi warna baru ketika hasil amendemen tersebut mengusung nuansa pencerahan dengan membentuk Komisi Yudisial. Langkah pemikiran yang

1 Terungkap pada masa setelah kemerdekaan, Soekarno pada saat itu kerap mengintervensi perkaraperkara tertentu dalam proses peradilan. Lebih lanjut pada masa orde baru Soeharto dengan kooptasi politiknya terhadap jabatan ketua Mahkamah Agung. Sebastian Pompe, Runtubnya Institusi Mabkamah Agung, Lembaga Kajian dan Advokasi Untuk Independensi Peradilan, Jakarta, 2012, hlm. 98 dan 165. 
sangat maju ketika virus mafia peradilan kian melembaga dalam kekuasaan yudikatif.

Hadirnya Komisi Yudisial seolah menjadi puncak harapan para justice seeker dalam mengawal proses peradilan, khususnya wakil tuhan di muka bumi. Komisi Yudisial mempunyai wewenang mengusulkan pengangkatan hakim agung dan wewenang lain dalam rangka menjaga, menegakkan kehormatan, keluhuran martabat serta perilaku hakim. ${ }^{2}$ Kewenangan ini secara otomatis berfungsi untuk menjamin perekrutan hakim agung yang kredibel, dan menjaga kontinuitas hakimhakim yang bertugas di lapangan, untuk tetap berpegang teguh pada nilai-nilai moralitasnya sebagai seorang hakim yang patut memiliki integritas dan kepribadian tidak tercela, jujur, adil, serta menjunjung tinggi nilai-nilai profesionalisme.

Hubungan kausalitas yang timbul, membawa konsekuensi logis agar warga negara maupun para justice seeker di luar struktur resmi lembaga peradilan, dapat berpartisipasi mulai dari proses rekruitmen, kinerja, sampai dengan kemungkinan pemberhentian hakim (impeachment of judge). Namun setelah hampir melewati fase selama satu dekade lebih, political will yang di usung awal-awal reformasi tersebut banyak menuai kebuntuan. Khususnya dalam hal pengangkatan dan pemberhentian hakim di Indonesia. Dalam hal pengangkatan hakim, landasan konstitusional dan level undang-undang seolah-olah mengatur secara terpisah sistem pengangkatan hakim karier, hakim agung, dan hakim konstitusi. Lebih satu dekade ternyata praktik ini menyisakan sejumlah masalah dan berjalan secara tidak linear (non integrated judiciary system).

Misalnya dalam hal sistem pengangkatan hakim karier. Belum lama ini, undang-undang paket kekuasaan kehakiman harus berujung uji materi di Mahkamah Konstitusi. Hal ini terkait dengan penolakan jajaran hakim Mahkamah Agung yang resisten terhadap keterlibatan Komisi Yudisial dalam pengangkatan hakim karier. Semakin diperburuk ketika Mahkamah Konstitusi (MK) mengabulkan seluruh permohonan Ikatan Profesi Hakim di Indonesia (IKAHI).

${ }^{2}$ Lihat Pasal 24B UUDN RI Pasca Amandemen. 
MK menyatakan bahwa keterlibatan KY dapat mengganggu tatanan independensi peradilan.

Dalam hal pengangkatan hakim agung pun demikian. Bangunan relasi kekuasaan yang melibatkan Komisi Yudisial (KY), Dewan Perwakilan Rakyat (DPR), dan Presiden ${ }^{3}$ harus kembali di luruskan oleh Mahkamah Konstitusi (MK). Melalui putusan MK, relasi antara KY-DPR dan Presiden kembali dirumuskan dengan meminimalisir peran DPR dalam memilih hakim agung. Imbasnya DPR tidak lagi mempunyai peran dalam "memilih" calon hakim agung yang diajukan oleh KY, melainkan hanya dalam hal menyetujui atau tidak (right to confirm). ${ }^{4}$

Dalam hal pengangkatan hakim Mahkamah Konstitusi (MK) juga demikian. Kewenangan atributif yang dijamin secara konstitusional dalam UUD perlu ditafsirkan secara detail (atomistik) dalam level undang-undang. Sembilan hakim konstitusi yang diangkat oleh Presiden yang masing-masing tiga orang berasal dari DPR, MA, dan Presiden 5 perlu kembali disempurnakan. Undang-undang tidak secara jelas mengatur mekanisme seleksi yang transparan dan akuntabel terhadap hakim konstitusi. Tidak heran banyak legalitas pengangkatan hakim Mahkamah Konstitusi berujung di PTUN karena dianggap tidak transparan dan akuntabel. Misalnya saja Akil Mochtar dari DPR, Patrialis Akbar dari Presiden, dan baru-baru ini Suhartoyo dari Mahkamah Agung yang prosesnya dinilai kurang transparan dan akuntabel.

Sengkarut permasalahan dalam pengangkatan hakim di Indonesia, secara otomatis berpengaruh besar terhadap sistem pemberhentiannya. Artinya, jika proses "hulunya" bermasalah sudah dapat dipastikan "hilirnya" pun bermasalah.

Aspek pemberhentian hakim menjadi isu yang patut dibedah kembali pasca amandemen. Merebaknya berbagai skandal yang melibatkan hakim dari berbagai institusi peradilan, telah membuka kembali perdebatan tentang akuntabilitas peradilan. Jika merunut praktik yang terjadi di Indonesia, terdapat proses pemberhentian (impeachment process) hakim yang kabur antara hakim karir, hakim agung, dan hakim konstitusi. Masing-masing hakim mempunyai cara serta proses

${ }^{3}$ Lihat Pasal 24A ayat (3) UUDN RI Pasca Amandemen.

${ }^{4}$ Lihat Putusan MK Nomor 27-PUU/XI/2013.

${ }^{5}$ Lihat Pasal 24C ayat (3) UUDN RI Pasca Amandemen. 
pemberhentian yang berbeda. Proses yang tidak berimbang mewarnai kekuasaan yudikatif jika melihat praktik pemberhentian hakim selama ini.

Dengan dalih independensi peradilan seolah tidak ada cabang kekuasaan lain yang bisa mengimbangi proses pemberhentian hakim di Indonesia. Padahal, ketika Judicial Council (Komisi Yudisial) di adopsi dalam struktur ketatanegaraan Indonesia, sudah semestinya organ ini bisa menjadi wadah awal dalam merumuskan judicial impeachment process dengan melibatkan cabang kekuasaan lain seperti yang sudah dipraktikan di negara-negara lain. Namun momentum tersebut hilang karena berbenturan dengan model one roof system pada kekuasaan yudikatif.

One roof system kini perlahan-lahan bergerak sebagai instrumen kekuasaan bergaya hak milik. Sistem pemberhentian hakim seolah menjadi otoritas penuh Mahkamah Agung dan Mahkamah Konstitusi, tanpa diikuti perimbangan cabang kekuasaan lain. Proses ini menjadi irasional jika melihat status hakim sebagai pejabat negara (state aparatur).

Hasil amandemen konstitusi dan integrasi dalam level undang-undang, belum mengatur secara jelas terkait dengan sistem pemberhentian hakim (judicial impeachment process) secara terpadu dan koheren di Indonesia. Perlunya pembenahan dalam judicial impeachment process tentunya menjadi indikator akuntabilitas kekuasaan yudikatif terhadap cabang kekuasaan lainnya. Tujuan utama dalam mengusung judicial impeachment process bukan hanya sekedar menciptakan akuntabilitas peradilan, tetapi yang lebih penting dan strategis agar terdapat gagasan penyempurnaan terkait mekanisme pemberhentian hakim dalam rumpun kekuasaan yudikatif.

Perlunya desain ulang (redesign) sistem pengangkatan dan pemberhentian hakim di Indonesia menjadi kajian penting dalam menggagas penyempurnaan kekuasaan yudikatif di Indonesia. Pembaharuan dibutuhkan mengingat perkembangan masyarakat Indonesia yang semakin demokratis. Para justice seeker yang semakin menuntut adanya sistem pengangkatan dan pemberhentian hakim yang efektif, efisien, profesional, transparan, akuntabel dan terpercaya.

Hal ini tentu menjadi topik yang menarik. Mengingat, penelitian-penelitian terdahulu belum mampu menggagas redesain sistem pengangkatan dan 
pemberhentian hakim di Indonesia. Oleh karena itu, kajian ini perlu direspon dalam ruang lingkup akademik. Kemudian dipandang layak untuk melakukan penelitian lebih lanjut, dan menuangkannya ke dalam bentuk penelitian.

\section{Rumusan Masalah}

Berdasarkan latar belakang di atas, maka dirumuskan permasalahan yang akan dikaji yaitu bagaimana redesain sistem pengangkatan dan pemberhentian hakim di Indonesia?

\section{Tujuan Penelitian}

Penelitian ini bertujuan untuk memperoleh formulasi redesain sistem pengangkatan dan pemberhentian hakim. Redesain dilakukan dengan merumuskan ulang desain sistem pengangkatan sampai dengan pemberhentian hakim di Indonesia.

\section{Metode Penelitian}

Metode penelitian yang digunakan dalam penelitian ini adalah metode penelitian kualitatif. Penelitian ini merupakan penelitian yuridis normatif yang merupakan penelitian pustaka tentang kajian hukum positif bersifat preskriptif. 6 Pendekatan yang dipakai antara lain pendekatan peraturan perundang-undangan, pendekatan historis, dan pendekatan konseptual. ${ }^{7}$ Data yang dipakai adalah data sekunder. Bahan hukum yang digunakan dalam penelitian ini adalah bahan hukum primer berupa hukum tertulis yang mengikat, bahan hukum sekunder berupa risalah undang-undang, buku, jurnal, artikel, dan bahan hukum tersier berupa kamus-kamus. ${ }^{8}$

\footnotetext{
${ }^{6}$ F. Sugeng Istanto, Penelitian Hukum, Cv Ganda, Yogyakarta, 2007, hlm 29.

7Peter Mahmud Marzuki, Penelitian Hukum, Kencana Prenada, Media Group, Jakarta, 2005, hlm 29.

8 Soerjono Soekanto, Pengantar Penelitian Hukum, UI Press, Jakarta, 1986, hlm 51.
} 


\section{Hasil Penelitian dan Pembahasan}

\section{Redesain Pengangkatan \& Pemberhentian Hakim}

Dalam merumuskan redesain sistem pengangkatan dan pemberhentian hakim dalam rumpun kekuasaan yudikatif, hasil penelitian menunjukkan terdapat tiga hal yang menjadi dasar reformulasi. Pertama, menata landasan konstitusional. Kedua, merit sistem pengangkatan hakim. Ketiga, menggagas jalur impeachment hakim.

\section{Menata Landasan Konstitusional}

Gagasan amandemen kelima UUD 1945 bukanlah hal yang tabu untuk diperbincangkan. Refleksi konstitusi selama lebih dari satu dekade memperlihatkan secara jelas begitu banyak kelemahan yang urgen untuk dibenahi. Khususnya dalam rumpun kekuasaan yudikatif, menata kembali landasan konstitusional merupakan hal ihwal untuk mewujudkan stabilitas penyelenggaraan kekuasaan yudikatif.

Terdapat beberapa materi muatan yang wajib direformulasikan agar politik hukum kekuasaan yudikatif memiliki kejelasan konstitusional (clear constitutional arrangements). Pertama, meluruskan kembali tafsir independensi peradilan. Tentu pertanyaan yang muncul adalah seperti apa kehendak independensi peradilan yang akan dijamin dalam konstitusi?

Secara tekstual, konstitusi terlalu memberikan definisi independensi peradilan yang sangat minimalis namun ditafsirkan secara liberal. Jika menganalisis Pasal 24 ayat (1) UUD Pasca Amandemen yang menyatakan "Kekuasaan Kehakiman merupakan kekuasaan yang merdeka untuk menyelenggarakan peradilan guna menegakkan hukum dan keadilan", definisi kemerdekaan kekuasaan kehakiman (judicial independence) menjadi konsep yang sangat minimalis. Sebab kemerdekaan kehakiman menjadi kabur (vague) dalam arti yustisi ataukah arti non yustisi. Kekaburan ini kemudian diperumit melalui aturan undang-undang (further regulation) yang menyatakan kemerdekaan tersebut mencakup seluruh aspek baik yustisi maupun non yustisi. 
Jika mengacu pada deklarasi internasional mengenai penyelenggaraan kekuasaan yudikatif, terdapat beberapa instrumen yang menafsirkan tentang independensi peradilan (judicial independence). Syracuse Principles 1981 memberi definisi bahwa;

"Setiap hakim bebas untuk memutuskan suatu masalah sesuai dengan fakta yang ditemukannya dan pengertiannya, tanpa pengaruh yang tidak layak, bujukan, atau tekanan-tekanan, langsung atau tidak langsung, pada setiap tingkatan. Kemudian lebih lanjut dinyatakan bahwa badan peradilan independen dari eksekutif dan legislatif."9

IBA Minimum Standards of Judicial Independence 1982 memberi pengertian bahwa independensi dibagi menjadi dua aspek yaitu independensi personal dan independensi substantif.

"Independensi personal merupakan syarat dan kondisi untuk menjamin agar hakim secara individual tidak berada di bawah kontrol eksekutif. Independensi substantif berarti dalam menjalankan fungsinya sebagai hakim, hanya terikat pada hukum dan keyakinannya."10

Montreal Universal Declaration on the Independence of Justice 1983 memberi pengertian bahwa;

"Seorang hakim harus bebas, dan menjadi kewajibannya untuk memutuskan perkara yang dihadapi secara imparsial, berdasarkan penilaiannya terhadap fakta dan pemahamannya terhadap hukum, tanpa batasan, pengaruh, bujukan,tekanan, ancaman, atau intervensi langsung, dari pihak manapun atau untuk alasan apapun. Kekuasaan kehakiman independen terhadap eksekutif dan legislatif." 11

UN Basic Principles of the Independence of Judiciary 1985 memberi penafsiran mengenai independensi peradilan bahwa;

"Kekuasaan kehakiman harus memutuskan perkara yang dihadapinya secara tidak memihak, berdasarkan fakta dan menurut hukum, tanpa batasan, pengaruh, bujukan,tekanan, ancaman, atau intervensi, langsung atau tidak langsung, dari pihak manapun atau untuk alasan apapun." 12

\footnotetext{
${ }^{9}$ Lihat Siracusa Principle 1981, Definition Part II, Art 2 (1),(2).

${ }^{10}$ Lihat IBA Minimum Standards of Judicial Independences 1982, Pasal 1 Huruf (a), (b), dan (c).

${ }^{11}$ Montreal Universal Declaration on the Independence of Justice 1983, Pasal 2.02, dan Pasal 2.04.

12 UN Basic Principles of the Independence of Judiciary 1985, Independent of Judiciary, Angka (2).
} 
Beijing Principles 1995, memberi penafsiran mengenai independensi peradilan bahwa;

Kekuasaan kehakiman harus memutuskan perkara yang dihadapinya secara tidak memihak, berdasarkan penilaiannya terhadap fakta dan pemahamannya terhadap hukum, tanpa pengaruh yang tidak seharusnya langsung atau tidak langsung dari pihak manapun. ${ }^{13}$

The Bungalore Principles of Judicial Conduct 2002, memberi penafsirannya mengenai independensi peradilan bahwa;

“Independensi kekuasaan kehakiman merupakan hal yang diwajibkan untuk tegaknya rule of law dan suatu jaminan mendasar terhadap peradilan yang jujur. Seorang hakim harus mempertahankan dan menunjukkan independensi kekuasaan kehakiman baik secara individual maupun aspek institusional". ${ }^{14}$

Beberapa deklarasi internasional di atas, tidak ada yang memberikan definisi yang persis sama antara masing-masing deklarasi. Namun dapat ditarik kesimpulan bahwa independensi peradilan (judicial independence) lebih dititik beratkan pada persoalan yang bersifat yustisi atau teknis peradilan. Secara garis besar dapat dirumuskan, indikator independensi peradilan meliputi (1) aspek kelembagaan; sebagaimana posisi teoritiknya tidak menjadi bagian dari kekuasaan eksekutif ataupun legislatif. (2) aspek fungsional; dalam proses fungsinya menjalankan proses peradilan, tidak ada satupun bentuk tekanan atau intervensi dari cabang kekuasaan lain dalam hal yang bersifat teknis peradilan. Dan (3) aspek personal hakim; seorang hakim independen secara individu dalam memutuskan suatu perkara tanpa adanya tekanan dari rekan sejawat ataupun hierarki intitusi internal badan peradilan.

Dari penjelasan di atas dapat disimpulkan ranah non yustisi peradilan tidak mempunyai hubungan kausalitas dengan independensi peradilan. Praktik di beberapa negara pun juga memperlihatkan bahwa urusan non yustisi peradilan (court administration) diserahkan pada organ negara independen layaknya judicial council yang justru hadir sebagai bentuk akuntabilitas peradilan. Oleh karena itu kekuasaan kehakiman yang merdeka sebagaimana yang tercantum dalam UUD

\footnotetext{
13 Beijing Principles 1995, Pasal 3 Huruf (a).

14 The Bungalore Principles of Judicial Conduct 2002, Value 1, Independence.
} 
1945 pasca amandemen, bukanlah tafsir kemerdekaan kekuasaan sebebasbebasnya, dalam seluruh sendi-sendi penyelenggaraan kekuasaan kehakiman.

Kedua, menjamin eksistensi Komisi Negara Independen (independent agency) sebagai cabang kekuasaan baru. Perkembangan ketatanegaraan bangsa Indonesia saat ini, tidak bisa terlepas dari peran organ-organ negara independen. Menjamurnya organ negara independen pasca amandemen konstitusi menuntut adanya porsi tersendiri sebagai cabang kekuasaan keempat (the fourth branch of government).

Amerika adalah salah satu negara percontohan yang telah mengakui eksistensi organ negara independen sebagai cabang kekuasaan keempat (The headless fourth branch of government). Checks and balances tidak lagi dimaknai sebagai perimbangan kekuasaan antara eksekutif, legislatif dan yudikatif, melainkan telah berkembang dan diimbangi oleh fungsi organ negara independen. ${ }^{15}$ Apa yang dipraktikkan di Amerika menjadi pintu masuk ketatanegaraan Indonesia untuk mengusung tesis tersebut.

Perlunya kehendak politik untuk memberikan porsi tersendiri di dalam konstitusi bukanlah hal yang mustahil. Komisi Yudisial (KY), Komisi Pemilihan Umum (KPU), Komisi Pemberantasan Korupsi (KPK), Badan Pemeriksa Keuangan (BPK) adalah beberapa diantara yang berpeluang mendapatkan constitutional importance dalam UUD. Pemberian porsi ini tidak lepas dari fungsinya menjaga stabiltas perimbangan kekuasaan (checks and balances).

Kehendak untuk mengakui eksistensi organ independen sebagai cabang kekuasaan baru, tidak lain untuk mengurangi resistensi terhadap relasi kekuasaannya dengan organ negara utama. Pengalaman ketatanegaraan telah membuktikan organ negara independen sangat rentan konflik dengan organ-organ utama yang begitu kuat dan berpola. KPK versus Polri, KY verus MA dan MK, adalah sejumlah kisah yang seharusnya diminimalisir bahkan tidak perlu ada ke depan nanti.

${ }^{15}$ Denny Indrayana, Negara Antara Ada dan Tiada; Reformasi Hukum Ketatanegaraan, Kompas, Jakarta, 2008, hlm. 28. Lihat juga Jimly Asshiddiqie, Perkembangan \& Konsolidasi Lembaga Negara Pasca Reformasi, Sinar Grafika, Jakarta, 2010, hlm. 8 
Kenyataan ini tidak bisa dipungkiri karena organ negara independen hanya mempunyai legitimasi yuridis yang sangat minimalis. Kelemahan posisi teoritik ini seringkali membuat organ negara independen sangat sulit untuk membangun corporate culture dengan mitra kerjanya. Oleh karena itu, untuk menguatkan fungsi KY dalam menjaga independensi dan akuntabilitas peradilan, perlu reposisi kelembagaan. Artinya KY tidak lagi menjadi bagian dalam kekuasaan kehakiman. KY bisa diposisikan secara khusus pada cabang kekuasaan baru yaitu kekuasaan organ negara independen, pada materi muatan konstitusi ke depan. Sebab memberi porsi KY dalam BAB IX Kekuasaan Kehakiman telah memberikan dampak buruk secara sistemik terhadap relasi kekuasaan KY, MA, bahkan MK.

Ketiga, mengurai benang kusut MA-KY dan MK. Ini menjadi materi muatan penting guna meluruskan kembali fungsi KY terhadap MA dan MK. Reformulasi relasi kekuasaan dapat ditempuh dengan cara redistribusi kekuasaan non yustisi terhadap KY. Konstitusi harus memberi kehendak yang jelas terhadap kewenangan yang diberikan KY tanpa mendikotomikan status hakim, hakim agung ataupun hakim konstitusi. Hal ini untuk memberi penegasan yang jelas terhadap subjek kewenangan KY.

Maka konsekuensi logis yang ditimbulkan adalah kekuasaan yudikatif tidak lagi mengadopsi one roof system manajerial peradilan. Artinya baik MA maupun MK di desain bergandengan dengan KY dalam menjaga stabilitas independensi dan akuntabilitas peradilan. Kehendak politik harus mendudukkan KY sebagai mitra utama MA dan MK dalam melaksanakan penyelenggaraan kekuasaan yudikatif dalam bidang non yustisi.

Pembagian kekuasaan non yustisi bisa diatur secara rinci oleh undangundang. Misalnya saja mengenai lingkup pengawasan KY terhadap semua hakim baik hakim karir, hakim agung maupun hakim konstitusi. Sistem seleksi hakim yang melibatkan KY, sampai dengan pembinaan hakim melalui promosi dan mutasi di Mahkamah Agung.

\section{Merit Sistem Pengangkatan Hakim}

Jika konstitusi telah melakukan purifikasi terhadap independensi peradilan, sampai dengan meluruskan relasi MA, KY, dan MK, tibalah saatnya undang- 
undang mengatur tata cara sistem pengangkatan hakim yang lebih merit. Harus diakui merit sistem dalam sistem pengangkatan hakim merupakan pendekatan yang paling popular diadopsi oleh negara-negara eropa kontinental.16 Bahkan laporan penelitian dari Global Corruption Report in Judicial System pada 2007 menyatakan bahwa untuk mencegah politisasi dalam sistem pengangkatan hakim di suatu negara, setidaknya memenuhi tiga indikator yaitu; (1) melibatkan organ negara independen, (2), berdasarkan sistem yang lebih merit (merit based system) dan (3) melibatkan partisipasi civil society. ${ }^{17}$ Oleh karena itu, formulasi merit sistem perlu dilakukan secara komprehensif meliputi hakim karir, hakim agung dan hakim konstitusi.

Pertama, pola pengangkatan hakim karir. Pasca putusan MK Nomor 43/PUU-XIII/2015, sistem seleksi hakim karir menjadi domain tunggal MA. ${ }^{18}$ Ini menjadi salah satu sistem yang fundamental harus dirombak. Sebab dalam pusaran kekuasaan MA, seleksi hakim karir menjadi tidak transparan. Persoalannya siapa yang mengawasi cara kerja MA dalam sistem seleksi hakim karir? Kepada siapa MA akuntabel? Oleh karena itu, perlu diformulasikan sistem yang jauh lebih merit.

Jika dulunya pengangkatan hakim karier hanya menjadi domain tunggal MA, maka sudah seharusnya KY dilibatkan untuk membuat sistem rekruitmen yang lebih bermutu. Sistem ini merupakan jawaban agar sistem rekruitmen hakim karier dilakukan secara partitsipatif, transparan dan akuntabel. Ketika KY mempunyai wewenang melakukan sistem rekruitmen (judicial recruitment) terhadap hakim agung, maka sudah seharusnya hakim karier juga menjadi ranah kewenangan KY. Melibatkan KY dalam seleksi dan pengangkatan hakim karir akan membuat sistem menjadi jauh lebih merit.

Tidak hanya itu, keterlibatan KY dalam sistem seleksi dan pengangkatan hakim karier merupakan cara adopsi perspektif masyarakat sipil. Termasuk di dalamnya screening terhadap rekam jejak bakal calon. Artinya melalui keterlibatan KY dalam proses seleksi dan pengangkatan hakim karier, masyarakat benar-benar

16 Peter Mc Cormick, "Selecting Trial Court Judges; A Comparison of Contemporary Practice" Study Commissioned by the Commission of Inquiry into the Appointment Process for Judges in Quebec, Canada, 1 September 2010.

${ }_{17}$ Global Corruption Report, Corruption in Judicial System, Transparancy Internasional; Cambridge University Press, New York, 2007, hlm. xxv

18 Lihat Putusan MK Nomor 43/PUU-XIII/2015. 
dilibatkan mulai dari proses seleksi hakim sampai dengan kemungkinan pemberhentian hakim.

Dalam hal mekanisme perimbangan kekuasaannya, calon hakim karir diusulkan oleh Komisi Yudisial ke parlemen (DPR atau DPD) ${ }^{19}$ setelah di seleksi bersama dengan Mahkamah Agung. Dalam hal ini parlemen menyatakan setuju atau tidak setuju (the right to confirm) kemudian calon hakim karir diangkat oleh Presiden melalui Keputusan Presiden. Persetujuan di parlemen tidak dalam bentuk fit and proper test tersendiri lagi namun dalam bentuk konfirmasi. Model seperti ini memberikan jaminan perimbangan di masing-masing cabang kekuasaan. Lebih dari pada itu, model ini semakin mengukuhkan status hakim karir tidak lagi identik dengan pegawai negeri sipil melainkan pejabat negara (state aparatur).

Kedua, dalam hal sistem seleksi dan pengangkatan hakim agung. Setelah adanya putusan MK Nomor 27 PUU/XI/201320, model pengangkatan hakim agung patut untuk dipertahankan. Sebab Putusan MK telah meluruskan kembali kekeliruan yang terjadi terkait relasi kekuasaan KY-DPR dan Presiden dalam pengangkatan hakim agung. Bahwa dalam sistem pengangkatan hakim agung, parlemen (DPR) hanya melakuakan persetujuan atas calon yang diajukan oleh KY. Persetujuan dilakukan sebagai right to confirm atau hak mengkonfirmasi tanpa perlu melakuakan seleksi lagi. Artinya DPR hanya berhak "meyetujui" atau "tidak menyetujui" calon hakim agung yang diusulkan oleh KY. Hal ini untuk menjauhkan calon hakim agung terhindar dari tangan-tangan politik atau kesepakatan politik "tertentu" dengan calon hakim agung.

Bagaimana dengan fungsi DPR dan Presiden, apakah hanya sebatas rubber stamp? Tentu tidak. Dalam konteks checks and balances, melibatkan DPR dan Presiden merupakan syarat wajib dalam konstelasi pengangkatan hakim agung sebagaimana yang dipraktikkan di negara-negara lain. Sebab DPR hadir sebagai representasi akuntabilitas publik terhadap sistem pengangkatan hakim agung. Perlu diingat baik DPR ataupun Presiden tetap mempunyai hak veto terhadap

${ }^{19}$ Peneliti berpendapat bahwa DPD perlu dilibatkan dalam sistem pengangkatan hakim karir. Formulasi ini didasarkan mengingat hakim karir bertugas berdasarkan wilayah kerja di daerah. Di samping itu DPD harus dilibatkan untuk mencegah penumpukan tugas di DPR. Mengingat DPR mempunyai tugas melakukan konfirmasi terhadap pengangkatan hakim agung dan hakim konstitusi.

${ }^{20}$ Lihat Putusan MK Nomor 27 PUU/XI/Tahun 2013 
calon hakim agung yang diusulkan oleh KY. Dalam keadaan tertentu veto tersebut dapat digunakan apabila calon hakim agung yang diusulkan terbukti melakukan perbuatan melanggar hukum.

Ketika terjadi kekeliruan yang mungkin tidak dapat disentuh oleh KY, maka DPR dan atau Presiden dapat melakukan penolakan terhadap calon hakim agung yang diusulkan. Perkembangan ketatanegaraan terakhir memperlihatkan dinamika pengangkatan pejabat negara. Misalnya saja dalam hal pengangkatan Kapolri BG, setelah diusulkan oleh Kompolnas dan diajukan ke DPR, KPK menetapkan calon tersebut sebagai tersangka, sehingga menimbulkan kegaduhan. Dalam hal ini kita bisa melihat Presiden melakukan veto untuk membatalkan pelantikan.

Contoh tersebut membuktikan dalam hal sistem pengangkatan hakim agung tetap diperlukan perimbangan kekuasaan dari parlemen ataupun presiden, jika sewaktu-waktu terdapat kegaduhan yang mendesak untuk diatasi. Model pengangkatan hakim agung seperti ini, memberi kesan adanya gradasi atau mekanisme berjenjang untuk mengangkat seorang hakim agung.

Ketiga, perihal pengangkatan hakim konstitusi. Redesain perlu dilakukan dengan melibatkan Komisi Yudisial (KY) sebagai panel untuk melakukan screening dan uji kelayakan (fit and proper test) terhadap calon hakim konstitusi yang diajukan oleh Presiden, DPR, dan MA. Mengapa perlu dilakukan oleh KY? KY merupakan organ independen yang cara kerjanya melibatkan rekomendasi dari masyarakat sipil terkait rekam jejak calon hakim. Desakan lapisan masyarakat menuntut adanya mekanisme pengangkatan hakim konstitusi yang lebih transparan, akuntabel dan partisipatif.

Political will mekanisme pengangkatan dapat dirumuskan dengan sistem yang lebih merit. Calon hakim dilakukan screening terlebih dahulu setelah diusulkan masing-masing 3 orang oleh Presiden, MA, ataupun DPR. Jika KY telah menyetujui usulan tersebut kemudian dimintakan persetujuan (right to confirm) kepada DPR. Setelah mendapatkan persetujuan dari DPR barulah dilantik secara seremonial oleh Presiden. Model seperti ini merupakan gagasan penyempurnaan dari model sebelumnya yang sangat beraroma penunjukan (political appointea). 
Dari masing-masing sistem pengangkatan hakim di atas, terlihat tata cara dan mekanisme yang berbeda terhadap pengangkatan hakim. Hal demikian bukanlah sebuah masalah. Sebab sistem pengangkatan hakim tidak bisa sematamata dapat diseragamkan satu sama lain antara hakim karir, hakim agung ataupun hakim konstitusi (depends on level of court). Namun terdapat satu bentuk keselarasan dari sistem pengangkatan hakim karir, hakim agung dan hakim konstitusi yaitu melibatkan Komisi Yudisial sebagai organ independen, dan menjaga keseimbangan relasi kekuasaan dari ekstra yudisial.

Mengapa model redesain melibatkan Komisi Yudisial (KY)? Harus diakui KY merupakan organ negara yang pada dasarnya didesain untuk menangani sengkarut permasalahan dalam sistem pengangkatan hakim. Paul Gilligan menyatakan "the most widely recognised power of a judicial council is its role in the appointment of judges". ${ }^{21}$ Pendapat di atas telah merumuskan bahwa salah satu karakteristik utama dari KY adalah melakukan seleksi dan pengangkatan hakim. Sebagai pengayaan teoritik berikut beberapa contoh negara yang telah menggunakan institusi sejenis KY dalam sistem rekruitmen hakim.

Tabel 1

(Judicial Council dan Judicial Recruitment Process) $^{22}$

\begin{tabular}{|c|c|c|c|c|}
\hline No & Negara & Nama Organ & Kewenangan & Dasar Hukum \\
\hline 1 & Italia & $\begin{array}{l}\text { Consiglio Superiore } \\
\text { Della Magistratura } \\
\text { (CSM) }\end{array}$ & $\begin{array}{l}\text { Seleksi, pengangkatan } \\
\text { hakim sampai dengan } \\
\text { promosi dan mutasi. }\end{array}$ & $\begin{array}{lr}\text { (Diatur dalam } \\
\text { Konstitusi) } \\
\text { Konstitusi } & \text { Italia } \\
\text { Pasal 105 } & \end{array}$ \\
\hline 2 & Thailand & Judicial Commission & $\begin{array}{l}\text { Memberikan } \\
\text { persetujuan } \\
\text { pengangktan dan } \\
\text { pemindahan hakim } \\
\text { sebelum diusulkan } \\
\text { kepada raja. Serta } \\
\text { memberikan } \\
\text { persetujuan } \\
\text { promosi hakim. atas }\end{array}$ & $\begin{array}{lr}\text { (Diatur } & \text { dalam } \\
\text { konstitusi) } & \\
\text { Pasal } & 220 \\
\text { Konstitusi } & \\
\text { Kerajaan } & \\
\text { Thailand } & \end{array}$ \\
\hline
\end{tabular}

21 Paul Giligan, Dalam ENCJ Project Team, Council For The Judiciary Report 2010-2011, With the support of the European Union, 2011, hlm 6.

22 Lihat Penelitian Wim Voermans, 2004, Komisi Yudisial di Negara Uni Eropa, kemudian diformulasikan ulang dengan tinjauan beberapa konstitusi di masing-masing negara. Lihat juga Komisi Yudisial RI, Perbandingan Komisi Yudisial di beberapa Negara, Sekjen KYRI-JPIP-USAID, Jakarta,2014, hlm. 37. 


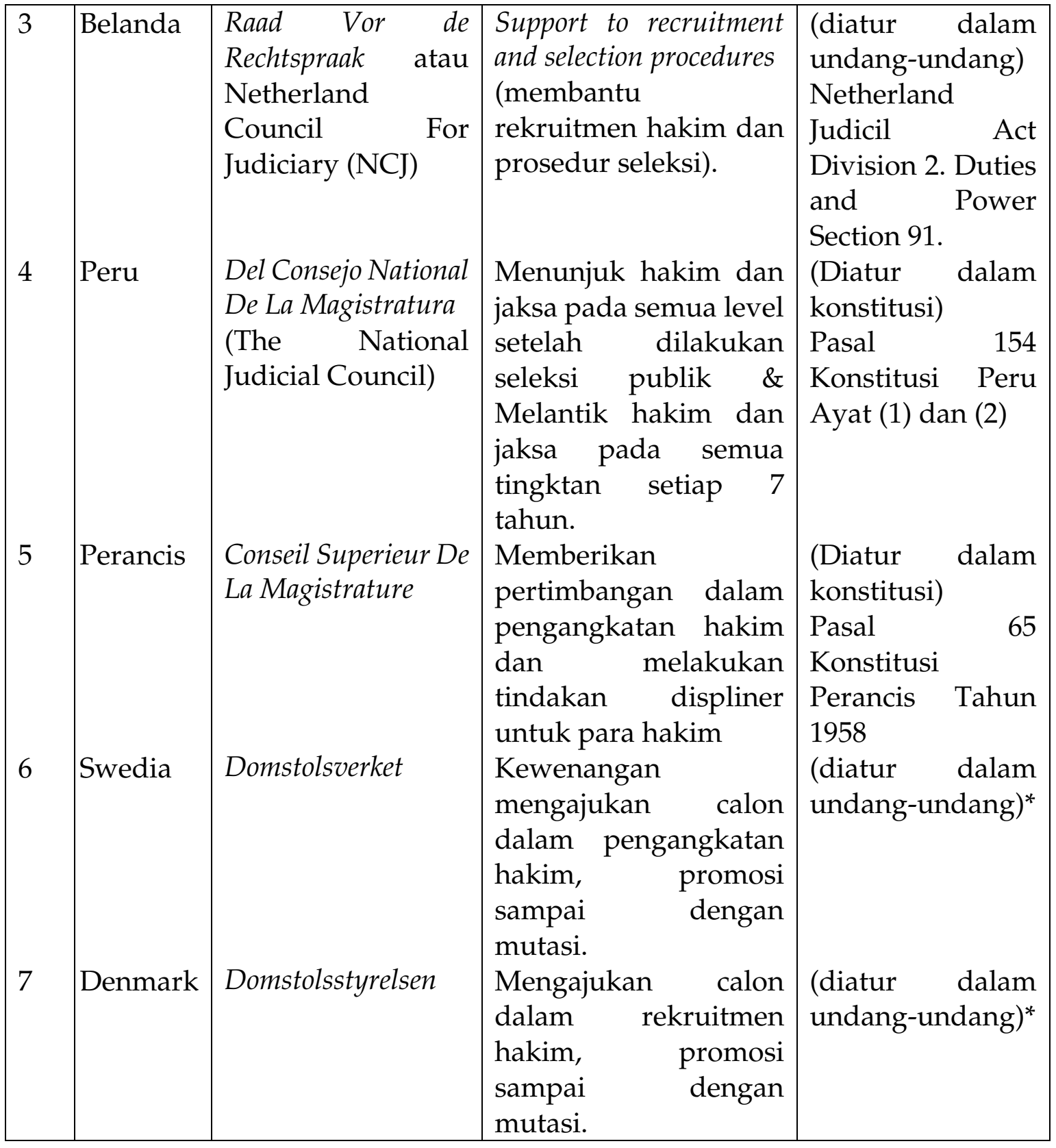

Beberapa negara di atas membuktikan bahwa peran Komisi Yudisial (judicial council) terhadap sistem pengangkatan hakim (judicial recruitment process) sangat penting. Beberapa pembenahan sistem pengangkatan hakim karir, hakim agung dan hakim konstitusi pada dasarnya merupakan gagasan penyempurnaan dari sistem yang telah ada. Ke depan redesain ini dapat menjadi kehendak dan spirit untuk menciptakan sistem seleksi dan pengangkatan hakim yang lebih baik pada kekuasaan yudikatif. 


\section{Menggagas Jalur Impeachment Hakim}

Jika proses pada "hulunya" telah disempurnakan, maka tiba saatnya untuk mengusung penyempurnaan pada proses "hilirnya". Untuk menggagas jalur impeachment hakim, pertama; langkah awal yang perlu dimuat adalah memberi jaminan bahwa tidak ada satupun hakim yang bebas dari pengawasan ekstern. Artinya Komisi Yudisial harus diberikan kewenangan untuk menjaga dan menegakkan keluhuran martabat serta perilaku hakim. Subjek hakim meliputi seluruh hakim di kekuasaan yudikatif baik itu hakim karir, hakim agung, maupun hakim konstitusi. Harus diakui fungsi Komisi Yudisial hadir sebagai pintu masuk laporan pengaduan masyarakat terhadap para hakim.

Kedua; oleh karena impeachment hakim merupakan instrumen pertanggungjawaban hakim terhadap warga negara. Maka sudah seyogyanya mekanismenya melibatkan lembaga perwakilan rakyat sebagai representasi publik. Dalam hal ini, mekanisme impeachment hakim wajib melibatkan DPR atau DPD sebagai lembaga politik. Mekanisme seperti ini tidak lain untuk menjamin konsistensi model impeachment hakim. Artinya jika sistem pengangkatannya melibatkan parlemen maka sudah seharusnya proses pemberhentiannya juga melibatkan parlemen. Ketiga, setelah melewati proses di parlemen, hakim diberhentikan secara administratif seremonial oleh Presiden, selaku kepala negara dengan keputusan Presiden.

Misalnya dalam hal impeachment hakim karir. Pemberhentian hakim karir dalam masa jabatannya dilakukan jika terbukti melakukan pelanggaran berat di bidang etika ataupun pelanggaran hukum yang dapat menjadi sebab pemberhentiannya. Dalam hal ini, ketika Komisi Yudisial menerima laporan pengaduan masyarakat, maka Komisi Yudisial melakukan investigasi terhadap hakim yang bersangkutan. Jika mempunyai cukup bukti yang kuat, maka terlebih dahulu hakim yang bersangkutan melakukan pembelaan di depan Majelis Kehormatan Hakim yang terdiri dari pihak Komisi Yudisial dan Mahkamah Agung. Artinya proses ajudikasi dihadapan Majelis Kehormatan Hakim. Jika terbukti melakukan pelanggaran berat, maka hakim yang bersangkutan diajukan oleh Dewan Perwakilan Rakyat atau Dewan Perwakilan Daerah untuk dimintakan 
persetujuan (right to confirm), kemudian diberhentikan oleh surat keputusan Presiden.

Dalam hal impeachment hakim agung, Pemberhentian hakim agung dalam masa jabatannya dilakukan jika terbukti melakukan pelanggaran berat di bidang etika ataupun pelanggaran hukum yang dapat menjadi sebab pemberhentiannya. Serupa dengan mekanisme hakim karir. Dalam hal ini, ketika Komisi Yudisial menerima laporan pengaduan masyarakat, maka Komisi Yudisial melakukan investigasi terhadap hakim yang bersangkutan. Jika mempunyai cukup bukti yang kuat, maka terlebih dahulu hakim yang bersangkutan melakukan pembelaan di depan Majelis Kehormatan Hakim yang terdiri dari pihak Komisi Yudisial dan Mahkamah Agung. Artinya proses ajudikasi dihadapan Majelis Kehormatan Hakim. Jika terbukti melakukan pelanggaran berat, maka hakim yang bersangkutan diajukan ke Dewan Perwakilan Rakyat (DPR) untuk dimintakan persetujuan (right to confirm), kemudian diberhentikan oleh Presiden.

Begitu juga dengan impeachment hakim konstitusi. Pemberhentian hakim konstitusi dalam masa jabatannya dilakukan jika terbukti melakukan pelanggaran berat di bidang etika ataupun pelanggaran hukum yang dapat menjadi sebab pemberhentiannya. Dalam hal ini, ketika Komisi Yudisial menerima laporan pengaduan masyarakat, maka Komisi Yudisial melakukan investigasi terhadap hakim yang bersangkutan. Jika mempunyai cukup bukti yang kuat, maka terlebih dahulu hakim yang bersangkutan melakukan pembelaan di depan Majelis Kehormatan Hakim yang terdiri dari pihak Komisi Yudisial dan Mahkamah Konstitusi. Artinya proses ajudikasi di hadapan Majelis Kehormatan Hakim. Jika terbukti melakukan pelanggaran berat, maka hakim yang bersangkutan diajukan ke Dewan Perwakilan Rakyat (DPR) untuk dimintakan persetujuan (right to confirm), kemudian diberhentikan oleh Presiden.

Jika melihat mekanisme jalur impeachment tersebut, baik hakim karir, hakim agung, dan hakim konstitusi, terdapat mekanisme perimbangan kekuasaan yang jelas. Perimbangan kekuasaan ini dibutuhkan agar mekanisme pemberhentian hakim berbanding lurus dengan proses pengangkatan hakim. Dengan demikian jalur impeachment hakim yang sebelumnya kabur, mendapatkan tempatnya sebagai wujud akuntabilitas peradilan terhadap warga negara dalam ranah non yustisi. 


\section{Penutup}

Redesain sistem pengangkatan dan pemberhentian hakim dapat dirumuskan dengan beberapa formulasi. Pertama, menata landasan konstitusional dengan meluruskan kembali kehendak independensi peradilan, mengakui eksistensi organ negara independen di dalam konstitusi hingga mengatur kembali benang kusut relasi kekuasaan Mahakamah Agung, Komisi Yudisial, dan Mahkamah Konstitusi. Kedua, mengusung merit sistem pengangkatan hakim dengan menjaga konstelasi prinsip checks and balances. Ketiga, menggagas jalur impeachment hakim secara integratif sebagai wujud akuntabilitas kekuasaan yudikatif dalam ranah non yustisi.

\section{Daftar Pustaka}

\section{Buku}

Asshiddiqie, Jimly, Perkembangan E Konsolidasi Lembaga Negara Pasca Reformasi, Sinar Grafika, Jakarta, 2010.

ENCJ Project Team, Council For The Judiciary Report 2010-2011, With the support of the European Union, 2011.

Fajrul Falaakh, Mohammad, Pertumbuhan dan Model Konstitusi Serta Perubahan UUD 1945 Oleh Presiden, DPR, dan Mahkamah Konstitusi, Gadjah Mada University Press, Yogyakarta, 2014.

Indrayana, Denny, Negara antara Ada dan Tiada; Reformasi Hukum Ketatanegaraan, Kompas, Jakarta, 2008.

Komisi Yudisial RI, Perbandingan Komisi Yudisial di beberapa Negara, Sekjen KYRIUSAID, Jakarta, 2014.

Mahmud Marzuki, Peter, Penelitian Hukum, Kencana Prenada, Media Group, Jakarta, 2005.

Naskah Komperhensif, Perubahan UUDN Republik Indonesia Tahun 1945, 2008, Buku VI Kekuasaan Kehakiman; Perubahan UUD mengenai Komisi Yudisial, Sekertariat Jendral dan Kepaniteraan Mahkamah Konstitusi RI, Jakarta.

Pompe, Sebastian, Runtuhnya Institusi Mahkamah Agung, Lembaga Kajian dan Advokasi Untuk Independensi Peradilan, Jakarta, 2012.

Sugeng Istanto, F., Penelitian Hukum, Cv Ganda, Yogyakarta, 2007.

Soerjono Soekanto, Pengantar Penelitian Hukum, UI Press, Jakarta, 2010. 
Voermans, Wim, Komisi Yudisial di beberapa negara Uni Eropa (Council for the Judiciary in EU Countries), Lembaga Kajian dan Advokasi untuk Independensi Peradilan (LeIP), Jakarta, 1999.

\section{Peraturan Perundang-Undangan;}

Undang-Undang Dasar Negara Republik Indonesia Tahun 1945.

Undang-Undang Nomor 22 Tahun 2004 tentang Komisi Yudisial, Lembaran Negara Republik Indonesia Tahun 2004, Tambahan Lembaran Negara RI Nomor 4415.

Undang-Undang Nomor 3 Tahun 2009 tentang Perubahan kedua Mahkamah Agung, Lembaran Negara Republik Indonesia Tahun 2009, Tambahan Lembaran Negara RI Nomor 3.

Undang-Undang Nomor 48 Tahun 2009 tentang Kekuasaan Kehakiman, Lembaran Negara Republik Indonesia Tahun 2009, Tambahan Lembaran Negara RI Nomor, 157.

Undang-Undang Nomor 49 Tahun 2009 tentang Peradilan Umum, Lembaran Negara Republik Indonesia Tahun 2009, Tambahan Lembaran Negara RI Nomor 5077.

Undang-Undang Nomor 50 Tahun 2009 tentang Peradilan Agama, Lembaran Negara Republik Indonesia Tahun 2009, Tambahan Lembaran Negara RI Nomor 5078.

Undang-Undang Nomor 51 Tahun 2009 tentang Peradilan TUN, Lembaran Negara Republik Indonesia Tahun 2009, Tambahan Lembaran Negara RI Nomor 5079.

Undang-Undang Nomor 18 Tahun 2011 tentang Perubahan Atas Undang-Undang Nomor 22 Tahun 2004 tentang Komisi Yudisial, Lembaran Negara Republik Indonesia, Tahun 2011, Tambahan Lembaran Negara RI Nomor, 106.

\section{Putusan Mahkamah Konstitusi}

Putusan MK Nomor 27-PUU/XI/2013.

Putusan MK Nomor 43/PUU-XIII/2015.

\section{Deklarasi Internasional}

Siracusa Principle 1981.

IBA Minimum Standards of Judicial Independences 1982.

Montreal Universal Declaration on the Independence of Justice 1983.

UN Basic Principles of the Independence of Judiciary 1985.

Beijing Principles 1995.

The Bungalore Principles of Judicial Conduct 2002. 
Jurnal, Makalah, dan Penelitian

Peter Mc Cormick, "Selecting Trial Court Judges; A Comparison of Contemporary Practice" Study Commissioned by the Commission of Inquiry into the Appointment Process for Judges in Quebec, Canada, 1 September 2010.

Global Corruption Report, Corruption in Judicial System, Transparancy Internasional; Cambridge University Press, New York, 2007,

Oce Madril, "Perbandingan Komisi Yudisial Di Asia", Bunga Rampai Komisi YudisialMembumikan Tekad Menuju Peradilan Bersih, Jakarta, 2011. 